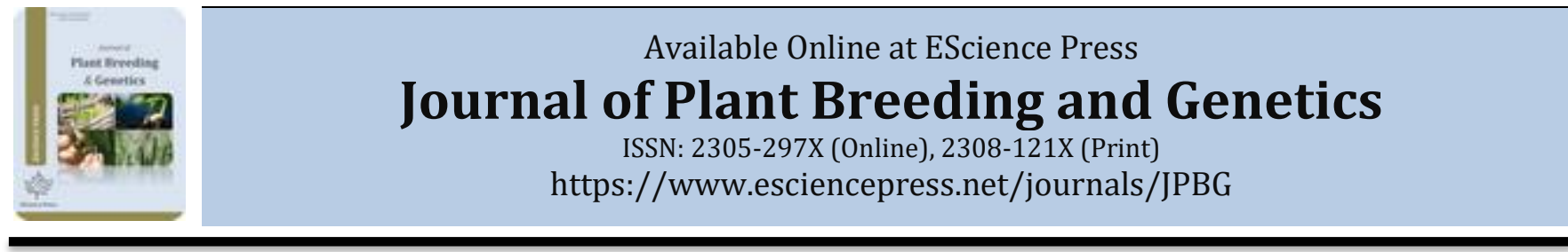

\title{
GENETIC ANALYSIS OF AGRONOMIC TRAITS OF WHEAT UNDER TERMINAL DROUGHT STRESS
}

\author{
aMohammad Dashtak*, bMohammad R. Bihamta*, aEslam Majidi, aReza A. Nejad \\ a Agronomy and Plant Breeding Department, Science and Research Branch, Islamic Azad University, Tehran, Iran. \\ b Agronomy and Plant Breeding Department, University of Tehran, Tehran, Iran.
}

Corresponding Author Email: mrghanad@ut.ac.ir; md_dashtaki@ut.ac.ir

\section{A B S T R A C T}

Seven wheat genotypes (Sirvan, Zarin, Pishgam, Karim, Baran, Heidary, and Rizhav) were crossed in diallel mating to develop $42 \mathrm{~F}_{1}$ 's hybrids. The resultant hybrids along with parents were evaluated during cropping season 2015-16 at agriculture and natural resources Pardis of Tehran University, Iran, using RCB design with 3 replications under drought stress and normal field conditions from the booting stage till physiological maturity. General combining ability (GCA) and specific combining ability (SCA) for agronomic traits were determined. The main objective of the research was the identification and proper selection of best-performing wheat parental genotypes and best $\mathrm{F}_{1}$ 's hybrids, based on GCA and SCA estimates. Significant differences were observed among the wheat genotypes for all the reported traits in this article. Results for combining ability analysis indicated that mean squares of GCA and SCA effects were significantly high for most of the traits. The estimates of $\sigma^{2}$ gca and $\sigma^{2}$ sca and its ratio $\left(\sigma^{2}\right.$ gca $/ \sigma^{2}$ sca $)$ indicated that non-additive genetic expression was dominant for most of the traits studied, then the heterosis breading is a useful program, however selection on superior hybrids should be postponed to the next generation for these traits in recombination program. It is concluded that Zarin, and Baran are recommended as the best general combiners for a future wheat breeding program. The maximum values of SCA observed in flag leaf length in normal and peduncle length in drought condition related to crosses of Rizhav with other parents. So, it is suggested these series of crosses can be down to improve these traits at the mentioned condition.

Keywords: GCA, SCA, Wheat genotypes, Drought stress, Diallel.

\section{INTRODUCTION}

Drought is one of the most devastating environmental stresses which limiting the productivity of agricultural crops (Zhu et al., 2010; Mollasadeghi et al., 2011). Reduction of crop yield under water deficit conditions is the primary concern of plant breeders (Nazari et al., 2010). The reaction of plants to drought stress depends on several factors such as developmental stage, severity and duration of importance, and genotype (Passioura, 2007). Among the crops, common wheat (Triticum aestivum L.) is the main food of most people in the world (Kawaura et al., 2008). According to USDA reports (2018), the total area under wheat cultivation in the worldwide is estimated at 46.0 million acres in the 2017 18. In wheat, germination, tillering and reproductive stages are considered as most sensitive traits to drought stress (Passioura, 2007). Katerji et al. (2009) reported that imposition of drought stress during ear formation and flowering stages of wheat reduced $37 \%$ and $18 \%$ in grain yield and straw yield.

Drought tolerance is one of the leading components of yield stability (Nazari et al., 2010). One effort to improve wheat tolerance to drought stress is through a breeding program. Before setting the breeding and selection methods breeders need to correct the character of genetic information. One way to obtain genetic information is Diallel cross analysis. Diallel analysis can be done using different methods such as Griffing (1956). In this method, the general combining ability (GCA) and the specific combining ability (SCA) can be conducted by using the appropriate statistical model to the estimation of components of variance; then, these variances can be used to predict genetic components such as additive and dominant effects of a population based on special 
assumptions.

This study was made to find appropriate parents for hybridization process of desirable plant traits under study as well as sorting of superior cross combinations for development of new cultivars with desirable attributes and future varietal development program.

\section{MATERIALS AND METHODS}

Genetic Material and Field Procedure: The studies were carried out at the Agricultural Research Station of Agriculture and Natural Resources Pardis of Tehran University in Karaj, Mohhamad Shahr $\left(35 \_56^{\circ} \mathrm{N}\right.$ and 50_58 ${ }^{\circ}$ ), Iran. The soil is classified as Loamy and characterized by pH 7.9 and EC 1.74 (ds. $\left.\mathrm{m}^{-1}\right)$. Average of annual rainfall at the experiment site is $243\left(\mathrm{~mm}\right.$. year $\left.{ }^{-1}\right)$. Average of rainfall and temperature ranged from 77.4 $\mathrm{mm}$ and $19.4{ }^{\circ} \mathrm{C}$ in November 2015 to $3.7 \mathrm{~mm}$ and $24.2^{\circ} \mathrm{C}$ in June 2016 while those ranged from $3.7 \mathrm{~mm}$ and $13.1^{\circ} \mathrm{C}$ in November 2016 to $53.9 \mathrm{~mm}$ and $25.8^{\circ} \mathrm{C}$ in June 2017, respectively, according to thirty years data of Alborz meteorological organization (Statistical data of Alborz meteorological center, 2018).

Seven genotypes (Baran, Haidari, Sirvan, Rijave, Karim, Zarinssss and Pishgam) between Thirty genotypes of wheat were chosen by agronomic and morphologic traits obtained from the previous cropping season (2015-16) and the other researcher's data about these genotypes under drought stress. Land preparation was done by ploughing and disking the soil at appropriate intervals and the sowing was done by hand. The selected genotypes were sown at three different dates to achieve proper synchronization of flowering between parents. A compound fertilizer in the form of NPK was applied before planting then four months later. Weeds control was carried out manually 4 times during the growing period by 2,4-D herbicide and Weeding. Cross-pollination was done using all possible combinations to give a total of 49 crosses. The set of forty-two $\mathrm{F}_{1}$ 's and their seven parents were grown alike last year cultivation in November 2016. Each trial had three replications, each of 2 rows $1 \mathrm{~m}$ in length and $0.2 \mathrm{~m}$ in width for each plot.

Experimental layout: The experiment was done using three replicates in a randomized complete block design (RCBD). The plant materials were grown under two moisture regimes of irrigation; the drought stress and well-watered (non-stress) experiments in reproductive stages. The amount of irrigation water given to each plot was estimated using the information of the evaporation pan and the data was obtained from a meteorological station located in the site. The irrigation rotations were calculated at the drought stress and normal field conditions by the cumulative evaporation after the first irrigation in spring. Irrigation levels were exerted at 90 $\mathrm{mm}$ cumulative evaporation for normal field condition and at $120 \mathrm{~mm}$ cumulative evaporation for drought stress level. The moisture treatments were applied from the booting stage (Zadoks 45) till physiological maturity (Zadoks 92). In order to better control of water entry, the valve was installed at the entrance of all blocks.

Data collection and analysis: Observations were made on five random plants of the two middle rows in each plot, their average was used. Yield components and agronomic traits including plant height (PL), ripening date (RD), spike length (SL), awn length (AK), flag leaf length (FLL), peduncle length (PeL), number of spikelet per spike (NSpS), main spike weight (MSW), number of spikes per plant (NSP), total weight of spikes per plant (TWSP), biological yield (BY), stem diameter (SD), grain weight of main spike (GWMS), harvest index (HI), kernel weight (actual weight of 1000 grains at 14\% moisture content) (KW), total leaf chlorophyll content (TLC), and yield of single plant (YSP) were evaluated.

The parents were selected based on performance, then data were analyzed using analysis of variance (ANOVA) with wheat genotypes for each irrigation rate (environments: Normal (E1) and drought stress (E2)). Data were subjected to analysis of variance using Statistical Analysis Software (SAS) Version 9.1 for Windows (SAS, 2000) by proc GLM. The significant genotypic variance of each trait was further partitioned to GCA, SCA and experimental error. Combining ability analysis and genetic component of measured traits was performed according to method 2, model I (fixed model) Griffing (1956) using Excel (2016) by programming. This method was calculated by following model:

$$
X i j=u+g i+g j+s i j+\frac{1}{b} \sum_{k} e_{i j k}
$$

Where, $\mathrm{u}=$ the population mean, gi $=$ the general combining ability effect of the ith parent, gj = the general combining ability effect of the jth parent, sij = the specific combining ability effect of the cross between ith and jth parents such that $s i j=s j i$ and eijk the environmental effect associated with ijkth observation. Comparing combining abilities of the used parents in the diallel crosses and identifying superior hybrid combinations is interested with this model. 


\section{RESULTS}

ANOVA: Diallel crosses were carried out in form of the full diallel cross in the field, while traits studied analysed according to method II of Griffing, given that, there were no difference among $\mathrm{F}_{1}$ 's and reciprocals according to ttest analysis (alpha $=0.01 \%$ ) (Results of t-test has not been reported).

Means observed of parents for traits under study under non-stress and drought stress conditions are presented in Table 1 (Top parents were shown with grey colour cells). Top parents mean or mean of two parents existed in crosses can be used for heterosis calculations for each $\mathrm{F}_{1}$ 's hybrid. The result of the analysis of variance for wheat traits under consideration under the drought stress and well-watered experiments is presented in Table 2.

Table 1. means observed of parents (P1: Sirvan, P2: Zarin, P3: Pishgam, P4: Karim, P5: Baran, P6: Heidary, and P7: Rizhav) for traits under consideration under non-stress and drought stress conditions. Top parents were shown with grey colour cells.

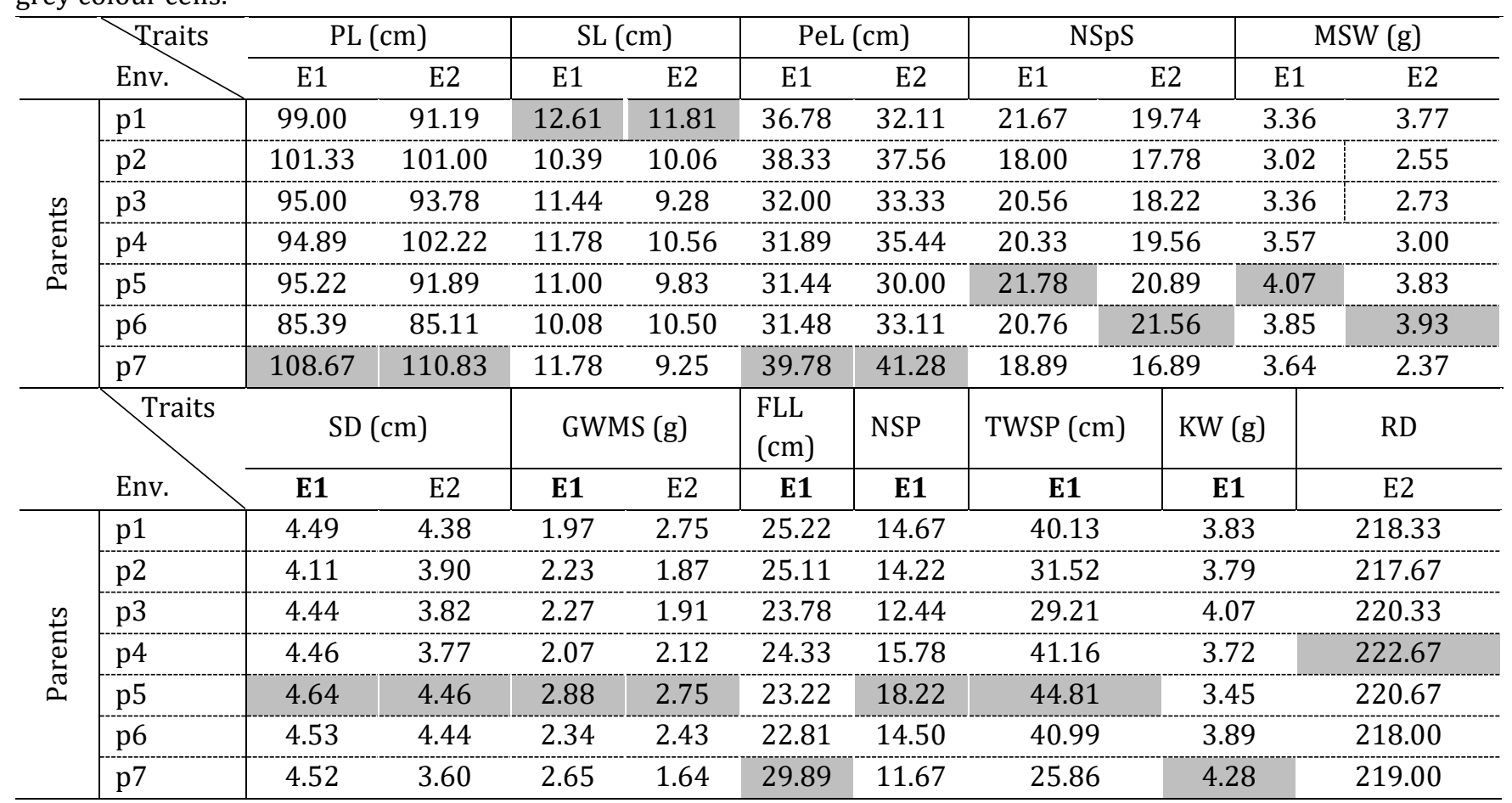

PH: Plant height; SL: Spike length; PeL: Peduncle length; NSpS: Number of spikelets per spike; MSW: Main spike weight; SD: Stem diameter; GWMS: Grain weight of main spike; FLL: Fag leaf length; NSP: Number of spikes per plant; TWSP: Total weight of spikes per plant; KW: Kernel weight; RD: ripening date;

Env.: Environments; E1: Normal field environment; E2: Drought stress environment;

The effects of genotypes were highly significant for $\mathrm{PH}$, SL, PeL, NSpS, MSW, SD, and GWMS traits in E1 and E2, RD in E2, FLL, NSP, TWSP, and KW in E1, indicated enough genetic variation in selected wheat genotypes while this effect was nonsignificant for other traits studied (Data has not been reported). According to results, variation among selected parents was observed for most of the traits; except FLL, NSP, KW and TWSP in E1 and RD in E2 that indicate these traits are varying in the mentioned environment.
Genetic components: Analysis of variances of genetic components for wheat traits under study under the drought stress and well-watered experiments is presented in Table 3. The effect of GCA was significant for PH, SL, PeL, NSpS, and GWMS traits in E1 and E2, FLL, NSP, and TWSP in E1 and RD in E2, while this effect was nonsignificant for MSW, SD in E1 and E2 and KW in E1. The effect of SCA was significant for all traits studied in E1 and E2. The genetic component of variances is assessed through the estimates of GCA and SCA variances (Table 3). 
Table 2. Analysis of variance of wheat traits under non-stress and drought stress conditions (method II Griffing).

\begin{tabular}{|c|c|c|c|c|c|}
\hline \multicolumn{2}{|c|}{ Sources of variation } & \multirow{2}{*}{$\frac{\mathrm{MS}_{\text {Block }}}{5}$} & \multirow{2}{*}{$\begin{array}{c}\text { MS Genotypes } \\
27\end{array}$} & \multirow{2}{*}{$\begin{array}{c}\text { MS Error } \\
\mathrm{m}^{*}\end{array}$} & \multirow{2}{*}{$\begin{array}{c}\begin{array}{c}\text { Coefficient of } \\
\text { variation }(\%)\end{array} \\
-\end{array}$} \\
\hline Traits & $\begin{array}{l}\text { Df } \\
\text { Env. }\end{array}$ & & & & \\
\hline \multirow{2}{*}{ PL } & E1 & 366.125 & $342.003^{* *}$ & 79.6194 & 9.9345 \\
\hline & E2 & 95.00965 & $447.01^{* *}$ & 78.1194 & 10.9429 \\
\hline \multirow{2}{*}{ SL } & E1 & 1.156543 & $1.94328^{* *}$ & 0.48313 & 6.08062 \\
\hline & E2 & 0.370795 & $1.84095^{* *}$ & 0.78021 & 8.25747 \\
\hline \multirow{2}{*}{ PeL } & E1 & 28.85693 & $58.4585^{* *}$ & 10.1723 & 9.41499 \\
\hline & E2 & 13.50762 & $70.4375^{* *}$ & 10.265 & 10.1468 \\
\hline \multirow{2}{*}{ NSpS } & $\mathrm{E} 1$ & 1.986081 & $7.50883^{* *}$ & 2.07021 & 7.24551 \\
\hline & E2 & 1.4178 & $6.92919^{*}$ & 4.03253 & 10.7301 \\
\hline \multirow{2}{*}{ MSW } & E1 & 2.237974 & $2.55802^{* *}$ & 1.30365 & 25.9646 \\
\hline & E2 & 0.570165 & $1.72436^{* *}$ & 0.63456 & 19.0956 \\
\hline \multirow{2}{*}{ SD } & $\mathrm{E} 1$ & 0.005948 & $0.31927^{* *}$ & 0.09998 & 6.78316 \\
\hline & E2 & 0.096947 & $0.43586^{* *}$ & 0.14332 & 8.48497 \\
\hline \multirow{2}{*}{ GWMS } & E1 & 88.53825 & $123.363^{* *}$ & 50.1862 & 66.0943 \\
\hline & E2 & 11.16178 & $84.4665^{* *}$ & 12.9984 & 29.5618 \\
\hline FLL & \multirow{4}{*}{ E1 } & 15.65709 & $11.6203^{* *}$ & 5.89598 & 10.1696 \\
\hline NSP & & 66.67766 & $16.9574^{*}$ & 9.10608 & 20.1715 \\
\hline TWSP & & 937.0474 & $176.771^{*}$ & 98.7398 & 23.0026 \\
\hline KW & & 0.149892 & $0.44284^{* *}$ & 0.1485 & 9.12163 \\
\hline $\mathrm{RD}$ & E2 & 3.092939 & $20.7167^{* *}$ & 7.80766 & 1.25603 \\
\hline
\end{tabular}

MS: Mean of the square; Df: Degree of freedom; $\mathrm{m}^{*}: \mathrm{Df} \mathrm{f}_{\mathrm{e}}=96$ (for all traits in Stress level and RD in E1), $\mathrm{Df}=94$ (for SD trait in $\mathrm{E} 1$ ), and $\mathrm{Df}_{\mathrm{e}}=95$ (for others).

*: F-test significant at $0.05 \%$ probability level.

**: F-test significant at $0.01 \%$ probability level.

ns: Non-significant at $0.05 \%$.

Note: For other abbreviations see Table 1.

The $\sigma_{A}^{2}$ is additive variance and $\sigma_{D}^{2}$ is dominance variance. According to results, the genetic component's magnitudes showed that the components of dominance variances were higher compared to additive components of variances for all characters. All characters showed less than unity values for GCA/SCA ratio. The highest ratio was observed in TWSP in E1 (0.128), while the lowest GCA/SCA ratio (0.004) was obtained from SD in E1.

General combining ability effects: It is primarily a function of additive genetic variance; it helps in the selection of suitable good general combining parents for hybridization. Data on GCA effects of wheat parent characters under tested environments are presented in Table 3. GCA effects was significant for most of the traits studied (except grey cells). It was noticed that among parents, no parent was proved as good general combiner simultaneously for all traits and selected parents were not same in different conditions except P3 and P6 for NSpS either, P2 and P3 for GWMS. Genotypes with high and positive GCA have a major influence on the increase of trait. The significantly negative estimate of GCA indicated that these genotypes possess additive genes that reduce the trait. The genotypes shown by "a" have got higher and positive GCA for every trait under normal and drought stress conditions. 
Table 3. Combination analysis of variance and Genetic components of wheat traits under non-stress and drought stress conditions (method II, model 1 Griffing).

\begin{tabular}{|c|c|c|c|c|c|c|c|c|}
\hline \multicolumn{2}{|c|}{ Sources of variation } & \multirow{2}{*}{$\begin{array}{c}\mathrm{MS} \sigma_{G C A}^{2} \\
6\end{array}$} & \multirow{2}{*}{$\begin{array}{c}\mathrm{MS} \sigma_{S C A}^{2} \\
21\end{array}$} & \multirow{2}{*}{$\begin{array}{c}\mathrm{MS}_{\text {Error }} \\
\mathrm{m}^{*}\end{array}$} & \multirow{2}{*}{$\frac{\sigma_{g c a}^{2}}{\sigma_{s c a}^{2}}$} & \multirow[b]{2}{*}{$\sigma_{A}^{2}$} & \multirow[b]{2}{*}{$\sigma_{g}^{2}$} & \multirow[b]{2}{*}{$\sigma_{D}^{2}$} \\
\hline Traits & $\begin{array}{l}\text { Df } \\
\text { Env. }\end{array}$ & & & & & & & \\
\hline \multirow{2}{*}{$\mathrm{PH}$} & E1 & $159.035^{* * *}$ & $90.105^{* * *}$ & 0.14 & 0.115 & 35.310 & 17.655 & 89.965 \\
\hline & E2 & $94.55^{* * *}$ & $137.55^{* * *}$ & 0.136 & 0.114 & 20.982 & 10.491 & 137.418 \\
\hline \multirow{2}{*}{ SL } & E1 & $0.54^{*}$ & $135.7^{* * *}$ & 0.000848 & 0.009 & 0.122 & 0.061 & 135.742 \\
\hline & E2 & $0.86^{* * *}$ & $0.55^{* * *}$ & 0.001355 & 0.011 & 0.190 & 0.095 & 0.554 \\
\hline \multirow{2}{*}{ PeL } & E1 & $28.7^{* * *}$ & $11.53^{* * *}$ & 0.02 & 0.041 & 6.377 & 3.188 & 11.510 \\
\hline & E2 & $22.9^{* * *}$ & $14.57^{* * *}$ & 0.018 & 0.041 & 5.105 & 2.552 & 14.558 \\
\hline \multirow[b]{2}{*}{ NSpS } & E1 & $1.98^{* * *}$ & $1.64^{* * *}$ & 0.0036 & 0.019 & 0.440 & 0.220 & 1.636 \\
\hline & $\mathrm{E} 2$ & $2.38^{* * *}$ & $1.79^{* * *}$ & 0.007 & 0.026 & 0.528 & 0.264 & 1.791 \\
\hline \multirow{2}{*}{ MSW } & E1 & $0.22 \mathrm{~ns}$ & $0.34^{* * *}$ & 0.002 & 0.015 & 0.049 & 0.025 & 0.334 \\
\hline & E2 & $0.34 \mathrm{~ns}$ & $0.58^{* * *}$ & 0.001 & 0.010 & 0.076 & 0.038 & 0.578 \\
\hline \multirow{2}{*}{ SD } & E1 & $0.055 \mathrm{~ns}$ & $0.09^{*}$ & 0.0002 & 0.004 & 0.012 & 0.006 & 0.100 \\
\hline & E2 & $0.038 \mathrm{~ns}$ & $0.15^{* * *}$ & 0.0002 & 0.005 & 0.009 & 0.004 & 0.146 \\
\hline \multirow{2}{*}{ GWMS } & E1 & $2.37^{* * *}$ & $38.64^{* * *}$ & 0.09 & 0.092 & 0.507 & 0.254 & 38.558 \\
\hline & E2 & $3.74^{* * *}$ & $37.46^{* * *}$ & 0.023 & 0.046 & 0.828 & 0.414 & 37.435 \\
\hline FLL & \multirow{4}{*}{ E1 } & $3.25^{* * *}$ & $3.27^{* * *}$ & 0.01 & 0.031 & 0.720 & 0.360 & 3.263 \\
\hline NSP & & $6.33^{* * *}$ & $2.96^{* * *}$ & 0.016 & 0.039 & 1.403 & 0.702 & 2.948 \\
\hline TWSP & & $9.94^{* * *}$ & $50.36^{* * *}$ & 0.17 & 0.128 & 2.171 & 1.085 & 50.192 \\
\hline KW & & $0.12 \mathrm{~ns}$ & $0.128^{*}$ & 0.0003 & 0.005 & 0.026 & 0.013 & 0.128 \\
\hline $\mathrm{RD}$ & E2 & $1.97^{* * *}$ & $6.23^{* * *}$ & 0.014 & 0.036 & 0.434 & 0.217 & 6.217 \\
\hline
\end{tabular}

MS $\sigma_{G C A}^{2}$ : Mean of the square of general combining ability; MS $\sigma_{S C A}^{2}$ : Mean of the square of specific combining ability; $\sigma_{A}^{2}$ : Additive variance; $\sigma_{g}^{2}$ : Genotypic variance; $\sigma_{D}^{2}$ : Dominant variance

$* * *$ : F-test significant at $0.001 \%$ probability level.

Note: For other abbreviations see Table 1 and 2.

Specific combining ability effects: Sprague and Tatum (1942) indicated that estimates of GCA and SCA may be interpreted in terms of genes and gene action. GCA is an indication of genes with primarily additive effects while SCA is an indication of genes with dominance or epistatic effects. Therefore, Estimates of GCA and SCA can provide valuable information about the parents used. The estimation of SCA given in Table 5 revealed that $\mathrm{F}_{1}$ 's hybrids had significant SCA effect for all traits thereby, indicating good specific combinations for traits with SCA positive. Altogether, the maximum values of SCA observed in FLL in E1 and PeL in E2 related to cross P7 with other parents.

\section{DISCUSSION}

The ratio of $\sigma^{2} \mathrm{gca} / \sigma^{2}$ SSca often used by plant breeders as an indication of the primary type of gene effects for the trait of interest. A large $\sigma^{2}$ gca/ $\sigma^{2}$ SSca ratio implies primarily additive gene effects, whereas a low ratio implies dominant and/or epistatic gene effects are important (Griffing, 1956a; Bhullar et al., 1979). All of the traits under consideration were controlled by nonadditive components. In such cases, hybrids would be ideal, however, the selection on superior hybrid should be postponed to the next generation for these traits in recombination breeding. Muhammad (2009) reported the non-additive genetic effects for yield traits and stated that magnitude and direction of combining ability effects provide a guideline about efficient utilization of wheat parents in hybridization programs.

In wheat, significant differences were found for relative water content (RWC), leaf water potential (LWP), proline content (PC) and non-stressed yield (Yp) in irrigated condition, while relative water loss (RWL), RWC and stressed yield (Ys) exhibited significant differences in stress condition indicating the presence of genetic variation and consequently the possibility of genetic analysis and combining ability analysis revealed significant differences among the parents for RWC in the irrigated and CMS, PC and Ys in the non-irrigated conditions indicating the involvement of additive and non-additive gene action in their inheritance (Farshadfar and et al., 2014). 
Table 4. Estimation of general combining ability (gi) of 7 parents (P1: Sirvan, P2: Zarin, P3: Pishgam, P4: Karim, P5: Baran, P6: Heidary, and P7: Rizhav) for various traits in wheat under non-stress and drought stress conditions. All $g_{i}$ es are significant according to $t$-test (alpha $=0.05 \%$ ) except grey cells.

\begin{tabular}{|c|c|c|c|c|c|c|c|c|c|c|c|c|c|c|c|c|c|c|c|c|}
\hline \multicolumn{21}{|c|}{ Traits } \\
\hline & & \multicolumn{2}{|c|}{$\mathrm{PH}$} & \multicolumn{2}{|c|}{ SL } & \multicolumn{2}{|c|}{ PeL } & \multicolumn{2}{|c|}{ NSpS } & \multicolumn{2}{|c|}{ MSW } & \multicolumn{2}{|c|}{ SD } & \multicolumn{2}{|c|}{ GWMS } & \multirow{2}{*}{$\begin{array}{c}\text { FLL } \\
\text { E1 }\end{array}$} & \multirow{2}{*}{$\begin{array}{c}\text { NSP } \\
\text { E1 }\end{array}$} & \multirow{2}{*}{$\begin{array}{c}\text { TWSP } \\
\text { E1 }\end{array}$} & \multirow{2}{*}{$\begin{array}{c}\text { KW } \\
\text { E1 }\end{array}$} & \multirow{2}{*}{$\begin{array}{l}\text { RD } \\
\text { E2 }\end{array}$} \\
\hline & env. & E1 & E2 & E1 & E2 & E1 & E2 & E1 & E2 & E1 & E2 & E1 & E2 & E1 & E2 & & & & & \\
\hline \multirow{7}{*}{ 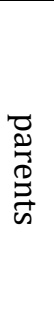 } & $\mathrm{p} 1$ & $2.415 \mathrm{a}$ & 1.100 & 0.030 & $0.345 \mathrm{a}$ & 0.531 & -0.739 & -0.227 & 0.169 & -0.315 & 0.038 & -0.107 & -0.029 & -0.880 & -0.099 & 0.030 & $1.055 \mathrm{a}$ & 0.502 & 0.030 & -0.722 \\
\hline & $\mathrm{p} 2$ & $2.038 \mathrm{a}$ & $3.207 \mathrm{a}$ & $0.837 \mathrm{a}$ & $0.287 \mathrm{a}$ & 0.687 & $1.478 \mathrm{a}$ & -0.012 & 0.098 & 0.081 & -0.006 & -0.104 & -0.037 & $0.346 \mathrm{a}$ & $0.716 \mathrm{a}$ & $0.837 \mathrm{a}$ & -0.406 & -0.774 & -0.089 & -0.389 \\
\hline & p3 & -0.599 & -1.131 & 0.265 & -0.436 & -0.705 & -0.209 & $0.720 \mathrm{a}$ & $0.250 \mathrm{a}$ & $0.180 \mathrm{a}$ & $0.200 \mathrm{a}$ & $0.079 \mathrm{a}$ & $0.080 \mathrm{a}$ & $0.749 a$ & $0.475 \mathrm{a}$ & 0.265 & -1.481 & -1.878 & $0.073 \mathrm{a}$ & -0.111 \\
\hline & $\mathrm{p} 4$ & -3.797 & -0.765 & -0.826 & -0.042 & -1.940 & -1.069 & 0.133 & -0.093 & 0.027 & -0.094 & 0.056 & -0.102 & -0.266 & -0.139 & -0.826 & -0.043 & 0.647 & -0.029 & $0.722 \mathrm{a}$ \\
\hline & p5 & $6.449 a$ & $3.267 \mathrm{a}$ & -0.470 & 0.266 & $2.653 \mathrm{a}$ & $1.924 \mathrm{a}$ & -0.304 & -0.186 & $0.074 \mathrm{a}$ & 0.031 & -0.016 & -0.001 & 0.141 & 0.154 & -0.470 & $0.864 \mathrm{a}$ & $0.744 \mathrm{a}$ & 0.033 & 0.185 \\
\hline & p6 & -6.294 & -6.222 & -0.407 & -0.115 & -2.393 & -2.529 & $0.390 \mathrm{a}$ & $0.723 \mathrm{a}$ & 0.017 & $0.201 \mathrm{a}$ & 0.029 & $0.083 \mathrm{a}$ & -0.169 & 0.186 & -0.407 & -0.013 & $1.083 \mathrm{a}$ & -0.186 & $0.259 \mathrm{a}$ \\
\hline & p7 & -0.212 & 0.544 & $0.571 \mathrm{a}$ & -0.305 & $1.167 \mathrm{a}$ & 1.145 & -0.699 & -0.960 & -0.066 & -0.369 & $0.063 \mathrm{a}$ & 0.005 & 0.079 & -1.293 & $0.571 \mathrm{a}$ & 0.025 & -0.325 & $0.168 \mathrm{a}$ & 0.056 \\
\hline
\end{tabular}

" a " are the highest positive values of GCA.

Note: For other abbreviations see Table 1 and 2.

Table5. Estimation of specific combining ability effects ( $\left.\mathrm{S}_{\mathrm{ij}}\right)$ of $21 \mathrm{~F}_{1}$ 's hybrids for various traits in wheat under non-stress and drought stress conditions. All $\mathrm{S}_{\mathrm{ij}} \mathrm{s}$ are significant according to t-test (alpha $=0.05 \%$ ) and the highest positive values of GCA for each trait in each Environment was shown with grey cells.

\begin{tabular}{|c|c|c|c|c|c|c|c|c|c|c|c|c|c|c|c|c|c|c|c|}
\hline \multicolumn{20}{|c|}{ Traits } \\
\hline & PH & & SL & & PeL & & NSpS & & MSW & & SD & & GWMS & & FLL & NSP & TWSP & KW & $\mathrm{RD}$ \\
\hline $\begin{array}{l}\text { Env. F1's } \\
\text { hybrids }\end{array}$ & E1 & E2 & E1 & E2 & E1 & E2 & E1 & E2 & E1 & E2 & E1 & E2 & E1 & E2 & E1 & E1 & E1 & E1 & E2 \\
\hline P1 x P2 & 11.475 & 6.415 & 1.893 & -17.749 & 1.357 & 1.055 & 0.370 & 0.870 & 0.470 & 0.073 & -0.493 & -0.080 & -0.711 & 3.389 & -24.670 & -0.950 & -1.684 & 0.265 & -0.306 \\
\hline P1 x P3 & 12.229 & 2.200 & 0.279 & -6.202 & 1.044 & -3.378 & -0.059 & 1.011 & -0.322 & 0.161 & -0.499 & -0.064 & -3.164 & 1.758 & 0.867 & 1.971 & 0.868 & 0.501 & -0.972 \\
\hline $\mathrm{P} 1$ x P4 & 8.203 & -0.125 & -0.48 & -17.199 & 6.088 & 5.013 & -2.991 & -1.552 & -0.422 & 0.436 & 0.031 & 0.144 & 0.245 & 3.858 & -26.352 & 4.074 & 3.751 & 0.013 & -0.361 \\
\hline P1 x P5 & -12.29 & -8.189 & -1.19 & -18.206 & -3.099 & -0.974 & -2.118 & -1.366 & -0.516 & 0.186 & 0.175 & -0.058 & -0.570 & 3.271 & -27.892 & 2.259 & 3.556 & -0.110 & 0.713 \\
\hline P1 x P6 & 4.358 & -0.700 & -0.24 & 201.883 & -0.157 & 0.388 & -0.920 & -2.691 & -0.008 & -0.245 & -0.057 & -0.412 & 0.133 & 2.026 & 1004.527 & 1.228 & -0.334 & 0.119 & 2.398 \\
\hline P1 x P7 & -11.09 & -8.2 & -3.54 & 1408.346 & -3.441 & -3.4 & -0.266 & & 43 & & 0.267 & & 12 & & 7161.940 & 35 & 1.049 & -0.071 & 1.306 \\
\hline P2 x P3 & -10.54 & -14.82 & 0.135 & -7.018 & -2.598 & -3.687 & 2.216 & 0.245 & 1.046 & 1.032 & 0.874 & 0.479 & 9.289 & 2.813 & 0.722 & -2.385 & 1.621 & -0.042 & 2.694 \\
\hline $\mathrm{P} 2 \times \mathrm{P} 4$ & 17.595 & 13.294 & 2.194 & -14.982 & 8.782 & 10.816 & -0.999 & 0.526 & 0.389 & 1.025 & -0.370 & 0.304 & 6.371 & 5.177 & -23.677 & -1.960 & -5.235 & 0.441 & -1.194 \\
\hline P2 x P5 & -2.899 & 5.231 & 1.482 & -15.990 & -0.405 & 4.829 & -0.127 & 0.712 & 0.295 & 0.775 & -0.225 & 0.103 & 5.556 & 4.590 & -25.217 & -3.775 & -5.430 & 0.318 & -0.120 \\
\hline P2 x P6 & 2.830 & 4.633 & 1.746 & 203.193 & 1.946 & 1.502 & -0.464 & -0.605 & 0.233 & 0.022 & -0.019 & -0.085 & 0.610 & 3.330 & 1006.515 & -0.528 & -1.276 & -0.019 & 4.731 \\
\hline P2 x P7 & -4.654 & -5.690 & -0.55 & 1408.576 & -3.893 & -1.955 & 1.647 & 1.894 & 0.443 & 0.909 & 0.004 & 0.272 & 0.124 & 6.514 & 7164.934 & 1.571 & 8.266 & -0.154 & -1.194 \\
\hline P3 x P4 & 15.158 & 0.130 & 1.685 & -17.317 & 8.655 & 6.127 & -1.149 & -0.768 & 0.699 & 0.518 & 0.128 & 0.315 & 2.725 & 4.836 & -24.185 & -0.999 & -0.771 & 0.444 & 0.639 \\
\hline
\end{tabular}




\begin{tabular}{|c|c|c|c|c|c|c|c|c|c|c|c|c|c|c|c|c|c|c|c|}
\hline x P5 & 5.335 & -7.933 & 973 & -18.325 & 0.532 & 0.140 & 277 & -0.583 & 0.605 & 0.268 & 0.272 & 0.113 & 1.910 & 4.250 & -25.726 & -2.814 & -0.965 & 0.321 & 1.713 \\
\hline $3 \times \mathrm{P} 6$ & 4.872 & 1.191 & 1.905 & 201.522 & 488 & 519 & 386 & .688 & 0.469 & 581 & 0.039 & 0.502 & 6.885 & 5.119 & 1006.674 & -2.536 & -1.291 & 0.246 & -0.602 \\
\hline P3 x P7 & -6.199 & -7.001 & .47 & 08.318 & .015 & 847 & 47 & 611 & 0.689 & 88 & 210 & 549 & 73 & 561 & 14 & .062 & .872 & 039 & 06 \\
\hline P4 x P5 & -0.115 & 0.647 & 0.915 & -17.623 & 0.045 & 0.496 & .840 & -0.388 & 0.276 & -0.029 & .003 & -0.081 & 5.860 & 255 & -25.784 & -1.375 & 2.565 & .551 & 0.546 \\
\hline P4 x P6 & 1.141 & -7.367 & 0.071 & 202.099 & 0.127 & -4.370 & .984 & -2.391 & 0.255 & -0.416 & 0.255 & -0.383 & 3.494 & 1.984 & 100 & -0.900 & -5.549 & 0.191 & 2.065 \\
\hline P4 x P7 & -16.88 & -14.27 & -4.91 & 408.262 & -6.970 & -5.091 & -0.241 & -0.384 & -0.161 & 0.304 & -0.164 & 0.381 & -3.538 & 1.502 & 716 & -0.418 & -1.951 & -0.436 & 2.472 \\
\hline P5 x P6 & 17.522 & 16.766 & 0.430 & 203.386 & 6.813 & 6.660 & -1.373 & -0.688 & -0.392 & -0.382 & -0.234 & -0.130 & 1.063 & 1.586 & 1005.199 & -0.161 & -5.692 & 0.256 & -1.935 \\
\hline P5 x P7 & 16.901 & -8.506 & -1.77 & 408.307 & 8.391 & -2.014 & -0.519 & -1.723 & 0.128 & -0.029 & -0.350 & -0.240 & -0.064 & 2.147 & 7163 & 0.055 & -0.729 & 0.264 & 1.472 \\
\hline P6 x P7 & -10.02 & -12.44 & -2.17 & 1408.122 & -5.131 & -7.236 & 1.520 & 2.602 & 0.227 & 1.100 & -0.073 & 0.322 & 2.333 & 5.735 & 7163.311 & 3.655 & 15.430 & -0.289 & 1.139 \\
\hline
\end{tabular}

P1: Sirvan, P2: Zarin, P3: Pishgam, P4: Karim, P5: Baran, P6: Heidary, and P7: Rizhav.

Note: For others, abbreviations see Tables 1, 2 and 3.

As well as, Farshadfar and et al., (2011) reported significant differences for grain yield, RWC, cell membrane stability, PC, and leaf chlorophyll content, and non-additive gene action in their inheritance according to combining ability analysis under drought stress in wheat. These results are general agreement with Muhammad (2009), Farshadfar and et al., (2011), and Farshadfar and et al., (2014).

Genotypes with high and positive GCA can be used in the development of high yielding genotypes through the pedigree selection and progeny selection or mass selection in later generations in generations in wheat Present finding are in confirmation with Kandil et al., (2016). Altogether, P2 and P5 registered best good general combiner for most of the traits under two environments while $\mathrm{P} 4$ registered poor general combiner.

In self-pollinated crops like wheat, SCA effects are not much important as they are mostly related to nonadditive gene effects excluding those of arising from complementary gene action or linkage effects they cannot be fixed in pure lines. Further superiority of the hybrids might not indicate their ability to yield transgressive segregates; rather SCA would provide satisfactory criteria (Jink and Jones, 1958). However, if a cross combination exhibiting high SCA as well as high performance having at least one parent as good general combiner for a specific trait, it is expected to throw desirable transgressive segregates in later generations (Singh Rajput and Kandalkar, 2018). The crosses with higher SCA indicated by grey cells in Table 5, for example, P2 x P4, P5 x P6 and P5 x P7 registered best good specific combiner for $\mathrm{PH}$ in $\mathrm{E} 1$ were the result of good $\mathrm{x}$ poor general combiner. There is a high probability that the offspring of these crosses will produce a higher plant in normal condition. In addition, four crosses (P4 x P7, P1 x P5, P6 x P7, and P2 x P3) had negative SCA effects, associated with low values of this trait in the progeny. In wheat, the exploitation of heterosis is still in its infancy. Ideally, in such situations, recurrent selection as proposed by Joshi, diallel selective mating as proposed by Jensen or the use of multiple crosses and biparental mating might be effective alternate approaches (Jain and Sastry, 2012).

Finally, Drought tolerance is a multigenic trait that expresses at different levels of the organization and different stages of development. Selection for drought tolerance, therefore, must involve molecular biological, biochemical and physiological approaches (László et al., 2002).

\section{CONCLUSIONS}

Results for combining ability analysis indicated that mean squares of GCA and SCA effects were significantly high for most of the traits. Diallel analysis demonstrated that non-additive effects played the major role in determining most of the characters studied. Therefore, both additive and non-additive gene actions were found to play an important role in controlling for drought resistance and other yield related characters with non-additive being more important. Thus, the heterosis breading is a useful 
program, however selection on superior hybrids should be postponed to the next generation for these traits in recombination program.

It is concluded that Zarin, and Baran are recommended as the best general combiners for a future wheat breeding program. The maximum values of SCA observed in flag leaf length in normal and peduncle length in drought condition related to crosses of Rizhav with other parents. So, it is suggested these series of crosses can be down to improve these traits at the mentioned condition.

\section{REFERENCES}

Bhullar, G.S., Gill, K.S. Khehra A.S. 1979. Combining ability analysis over $F_{1}-F_{2}$ generations in diallel crosses of bread wheat. Theoretical and Applied Genetics, 55:77-80.

Farashadfar, E., Mohammadi, M., Haghparast, R. 2011. Diallel Analysis of Agronomic, Physiological and Metabolite Indicators of Drought Tolerance in bread Wheat (Triticum aestivum L.). International Journal if Plant Breeding. 5(1): 42-47.

Farshadfar, E., ghaderi, A., Yaghotipoor, A. 2014. Diallel Analysis of Physiologic Indicators of Drought Tolerance in Bread Wheat (Triticum aestivum L.). 2(1): 1-7.

Griffing B. 1956. Concept of general and specific combining ability in relation to diallel crossing system. Australian Journal of Biological Sciences, 9:463-493.

Jain, S.K., Sastry, E.V.D., 2012. Heterosis and combining ability for grain yield and its contributing traits in bread wheat (Triticum aestivum L.). RRJAAS, 1(1): 17-22.

Jinks, J.L., Jones, R.M. 1958. Estimation of components of heterosis. Genetica.;43:223-234.

Kandil A. Sharief A., Hasnaa, A.E., Gomaa, S.M. 2016. Estimation of general and specific combining ability in bread wheat (Triticum aestivum L.). International Journal of agricultural research, $8(2): 37-44$.

Katerji, N., Mastrorilli, M., Hoornc, J.W., Lahmerd, F.Z., Hamdyd, A., Oweise, T. 2009. Durum wheat and barley productivity in saline-drought environments. European Journal of agronomy, 31(1): 1-9.

Kawaura, K., Mochida, K., Ogihara, Y. 2008. Genome-wide analysis for identification of salt-responsive genes in common wheat. Functional and Integrative Genomics. 8: 277-286.

László, E., Irma, T., Jolán, C., Attila, P., Ferenc, H., Margit, S., Mónika, O., László C., Mira, Z., László, S., János, G. 2002. Osmotic stress responses of wheat species and cultivars differing in drought tolerance: some interesting genes (advices for gene hunting). Acta Biologica Szegediensis Proceedings of the 7 th Hungarian Congress on Plant Physiology, S2-06, 46(3-4):63-65,

Mollasadeghi, V., Valizadeh, M., Shahryariand, R.A., Imani, A. 2011. Evaluation of end drought tolerance of 12 wheat genotypes by stress in dices. Middle-east Journal of Scientific Research, 7(2):241-247.

Muhammad, 0. 2009. Combining ability in wheat for seedling traits by line $\mathrm{x}$ tester analysis under saline conditions. Italian Journal Agronomy, 4(2): 13-18.

Nazari, L, Pakniyat, H. 2010. Assessment of drought tolerance in barley genotypes. Journal of Applied Science, 10:151-156.

Passioura, J.B. 2007. The drought environment: physical, biological and agricultural perspectives. Journal. Experimental Botany, 58(2): 113-117.

Singh Rajput, R., Kandalkar, VS. 2018. Combining ability and heterosis for grain yield and its attributing traits in bread wheat (Triticum aestivum L.). Journal of Pharmacognosy and Phytochemistry. 7(2): 113-119.

Sprague, G.F., Tatum, L.A. 1942. General versus specific combining ability in single crosses of corn. Journal of American Society of Agronomy, 34:923-932.

USDA (: United States department of agriculture). 2018.World Agricultural Supply and Demand Estimates: WASDE - 578, ISSN: 1554-9089.

Zhu, Q., Zhang, J., Gao, X., Tong, J., Xiao, L., Li, W., Zhang, H. 2010. The Arabidopsis AP2/ERF transcription factor RAP2.6 participates in ABA, salt and osmotic stress responses. Gene, 457:1-12. 
Publisher's note: EScience Press remains neutral with regard to jurisdictional claims in published maps and institutional affiliations.

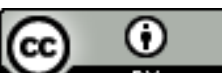

Open Access This article is licensed under a Creative Commons Attribution 4.0 International License, which permits use, sharing, adaptation, distribution and reproduction in any medium or format, as long as you give appropriate credit to the original author(s) and the source, provide a link to the Creative Commons license and indicate if changes were made. The images or other third-party material in this article are included in the article's Creative Commons license, unless indicated otherwise in a credit line to the material. If material is not included in the article's Creative Commons license and your intended use is not permitted by statutory regulation or exceeds the permitted use, you will need to obtain permission directly from the copyright holder. To view a copy of this license, visit http://creativecommons.org/licenses/by/4.0/.

(C) The Author(s) 2019. 